\title{
Varia
}

\section{The Communication from the Commission to the European Parliament, the Council, the European Economic and Social Committee and the Committee of the Regions: "Towards an EU Criminal Policy: Ensuring the effective implementation of EU policies through criminal law"}

\author{
(COM [2011] 573 final)
}

On 29th September, 2011, the European Commission published the aforementioned Communication. Though just a "communication" without any legal significance, the paper contains highly important guidelines in relation to the role criminal law is meant to play in a European context in the future. It attaches far greater importance to criminal policy decisions at the EU-level and - in general - contains a new strategy to be adopted by the Commission in relation to the use of criminal law. Uniform principles and sample language shall be applied in order to create consistent and coherent criminal law. The fundamental importance of the concept and ideas laid down in the Communication deserve to be taken seriously and must be discussed thoroughly (see also Editorial, p. 209). For these reasons, the editors wished to print an excerpt of the Communication in this issue of EuCLR.

\section{Towards an EU Criminal Policy: Ensuring the effective implementation of EU policies through criminal law}

.... An EU Criminal Policy should have as overall goal to foster citizens' confidence in the fact that they live in a Europe of freedom, security and justice, that EU law protecting their interests is fully implemented and enforced and that at the same time the EU will act in full respect of subsidiarity and proportionality and other basic Treaty principles.

\section{The added value of EU criminal law}

Certainly, criminal law is a sensitive policy field where differences amongst the national systems remain substantial, for example regarding sanction types and levels as well as the classification of certain conduct as an administrative or criminal offence. However, the EU can tackle gaps and shortcomings wherever EU action adds value. In view of the cross-border dimension of many crimes, the adoption of EU criminal law measures can help ensuring that criminals can neither hide behind borders nor abuse differences between national legal systems for criminal purposes. 


\section{Strengthening mutual trust}

Common minimum rules in certain crime areas are also essential to enhance the mutual trust between and the national judiciaries. This high level of trust is indispensable for smooth cooperation among the judiciary in different Member States. ...

\section{Ensuring effective enforcement}

Criminal law can play an important role to ensure the implementation of European Union policies. ... The Union alone cannot make sure that its rules, ..., have the desired effect for the citizen. Member States are obliged to ensure that Union policies are implemented and can usually decide themselves on the means of enforcement. In this respect, controls and inspections play a crucial role. In cases where the enforcement choices in the Member States do not yield the desired result and levels of enforcement remain uneven, the Union itself may set common rules on how to ensure implementation, including, if necessary, the requirement for criminal sanctions for breaches of EU law.

\section{Coherence and consistency}

While EU criminal law measures can play an important role as a complement to the national criminal law systems, it is clear that criminal law reflects the basic values, customs and choices of any given society. The Lisbon Treaty accepts this diversity.6 For this reason, it is particularly important to ensure that EU legislation on criminal law, in order to have a real added value, is consistent and coherent. 7

\section{Ensuring effective enforcement}

The legal framework under the Lisbon Treaty ... notably allows the EU institutions and Member States to work together on a clear basis towards a coherent and consistent EU criminal law which at the same time effectively protects the rights of suspected and accused persons and victims and promotes the quality of justice....

Criminal law measures comprise intrusive rules, which can result in deprivation of liberty.

This is why the Charter of Fundamental Rights - made legally binding by the Lisbon Treaty - provides important limits for EU action in this field. The Charter, being the compass of all EU policies, provides for a binding core of rules that protects citizens.

\section{SCOPE FOR EU CRIMINAL LAW}

The EU can adopt under Article 83 of the Treaty on the Functioning of the European Union (TFEU) directives with minimum rules on EU criminal law for different crimes.

First of all, measures can be adopted under Article 83(1) TFEU concerning a list of explicitly listed ten offences (the so-called 'Euro crimes").

Secondly, Article 83(2) TFEU allows the European Parliament and the Council, on a proposal from the Commission, to establish "minimum rules with regard to the 
definition of criminal offences and sanctions if the approximation of criminal laws and regulations of the Member States proves essential to ensure the effective implementation of a Union policy in an area which has been subject to a harmonisation measure". This clause does not list specific crimes, but makes the fulfillment of certain legal criteria a precondition for the adoption of criminal law measures at EU level. It is therefore notably in respect of Article 83(2) TFEU where an EU criminal policy is particularly warranted; and where this Communication intends to provide specific guidance. Most importantly, it is in this field where the EU institutions need to make policy choices whether to use or not to use criminal law (instead of other measures, such as administrative sanctions) as an enforcement tool; and to determine which EU policies require the use of criminal law as an additional enforcement tool.

\section{WHICH PRINCIPLES SHOULD GUIDE EU CRIMINAL LAW LEGISLATION?}

As in national law, EU criminal law legislation must be carefully considered. Criminal law, whether national or European, consists of rules with a significant impact on individuals. For this reason, and because criminal law must always remain a measure of last resort, new legislation requires the respect of fundamental legal principles.

\subsection{General principles to respect}

The general subsidiarity requirement for EU legislation must be given special attention with regard to criminal law. This means that the EU can only legislate if the goal cannot be reached more effectively by measures at national or regional and local level but rather due to the scale or effects of the proposed measure can be better achieved at Union level. ...

In addition, fundamental rights, as guaranteed in the EU Charter of Fundamental Rights and in the European Convention on the Protection on Human Rights and Fundamental Freedoms, must be respected in any policy field of the Union. Criminal law measures are fundamental rights-sensitive. They unavoidably interfere with individual rights, be it those of the suspect, of the victim or of witnesses. Ultimately, they can result in deprivation of liberty and therefore require particular attention by the legislator.

\subsection{A two-step approach in criminal law legislation}

The EU legislator should follow two steps when taking the decision on criminal law measures aimed at ensuring the effective implementation of EU policies which are the subject of harmonising measures. 


\subsubsection{Step 1: The decision on whether to adopt criminal law measures at all}

- Necessity and Proportionality - Criminal law as a means of last resort ("ultima ratio")

Criminal investigations and sanctions may have a significant impact on citizens' rights and include a stigmatising effect. Therefore, criminal law must always remain a measure of last resort. This is reflected in the general principle of proportionality (as embodied in the Treaty on European Union and, specifically for criminal penalties, in the EU Charter of Fundamental Rights). For criminal law measures supporting the enforcement of EU policies, the Treaty explicitly requires a test of whether criminal law measures are "essential" to achieve the goal of an effective policy implementation.

Therefore, the legislator needs to analyse whether measures other than criminal law measures, e.g. sanction regimes of administrative or civil nature, could not sufficiently ensure the policy implementation and whether criminal law could address the problems more effectively. This will require a thorough analysis in the Impact Assessments preceding any legislative proposal, including for instance and depending on the specificities of the policy area concerned, an assessment of whether Member States' sanction regimes achieve the desired result and difficulties faced by national authorities implementing EU law on the ground.

\subsubsection{Step 2: Principles guiding the decision on what kind of criminal law measures adopt}

Should Step 1 demonstrate the need for criminal law, the next question is which concrete measures to take.

\section{- Minimum rules}

EU legislation regarding the definition of criminal offences and sanctions is limited to "minimum rules" under Article 83 of the Treaty. This limitation rules out a full harmonisation.

At the same time, the principle of legal certainty requires that the conduct to be considered criminal must be defined clearly. However, an EU directive on criminal law does not have any direct effect on a citizen; it will have to be implemented in national law first. Therefore, the requirements for legal certainty are not the same as for national criminal law legislation. The key is the clarity for the national legislator about the results to be achieved in implementing EU legislation.

Regarding sanctions, "minimum rules" can be requirements of certain sanction types (e.g. fines, imprisonment, disqualification), levels or the EU-wide definition of what are to be considered aggravating or mitigating circumstances. In each case, the EU instrument may only set out which sanctions have to be made "at least" available to the judges in each Member State.

\section{- Necessity and proportionality}


The condition of "necessity" set out above also applies on the level of deciding which criminal law measures to include in a particular legislative instrument. The "necessity test" becomes the more important the more detailed the envisaged rules are with regard to the type and level of sanctions to be required from Member States. The explicit requirement of the Charter of Fundamental Rights that "the severity of the penalty must not be disproportionate to the criminal offence" applies.

\section{- Clear factual evidence}

To establish the necessity for minimum rules on criminal law, the EU institutions need to be able to rely on clear factual evidence about the nature or effects of the crime in question and about a diverging legal situation in all Member States which could jeopardise the effective enforcement of an EU policy subject to harmonisation. This is why the EU needs to have at its disposal statistical data from the national authorities that allow it to assess the factual situation. As part of its follow up action, the Commission will develop plans to collect further statistical data and evidence to deal with the areas covered by Article 325 (4) and Article 83 (2).

\section{- Tailoring the sanctions to the crime}

The development of criminal law legislation, notably to underpin the effectiveness of EU policies requires also careful consideration of, for example, the following issues:

- whether to include types of sanctions other than imprisonment and fines to ensure a maximum level of effectiveness, proportionality and dissuasiveness, as well as the need for additional measures, such as confiscation; and

- whether to impose criminal or non-criminal liability on legal persons, in particular with regard to crime areas where legal entities play a particularly important role as perpetrators.

What is the possible content of EU minimum rules on criminal law?

The definition of the offences, i. e. the description of conduct considered to be criminal, always covers the conduct of the main perpetrator but also in most cases ancillary conduct such as instigating, aiding and abetting. In some cases, the attempt to commit the offence is also covered.

All EU criminal law instruments include in the definition intentional conduct, but in some cases also seriously negligent conduct. Some instruments further define what should be considered as "aggravating" or "mitigating" circumstances for the determination of the sanction in a particular case.

Generally, EU legislation covers offences committed by natural persons as well as by legal persons such as companies or associations. The latter can be important in many areas, e. g. concerning responsibility for oil spills. However, in existing legislation, Member States have always been left with the choice concerning the type of liability of legal persons for the commission of criminal offences, as the concept of criminal liability of legal persons does not exist in all national legal orders. 
Furthermore, EU legislation can cover rules on jurisdiction, as well as other aspects that are considered part of the definition as necessary elements for the effective application of the legal provision.

Regarding sanctions, EU criminal law can require Member States to take effective, proportionate and dissuasive criminal sanctions for a specific conduct....

Sometimes, EU criminal law determines more specifically, which types and/or levels of sanctions are to be made applicable. Provisions concerning confiscation can also be included. It is not the primary goal of an EU-wide approximation to increase the respective sanction levels applicable in the Member States but rather to reduce the degree of variation between the national systems and to ensure that the requirements of "effective, proportionate and dissuasive" sanctions are indeed met in all Member States.

\section{WHICH ARE THE EU POLICY AREAS WHERE EU CRIMINAL LAW MIGHT BE NEEDED?}

Criminal law measures can be considered as an element to ensure the effective enforcement of EU policies, as recognized by the Treaty on the Functioning of the European Union. EU policies cover a broad variety of subjects, where common rules have been developed over the last decades for the well-being of citizens. These policy areas range from the customs union and internal market rules to the protection of the environment.

In all these policy areas, Member States are obliged to ensure that breaches of EU law are to be sanctioned with effective, proportionate and dissuasive penalties. Member States can in general choose the nature of the sanction which does not have to be criminal but could also be administrative.

Where the discretion of Member States in implementing EU law does not lead to the desired effective enforcement, it may be necessary to regulate, by means of minimum rules, at EU level which sanctions Member States have to foresee in their national legislation.

Approximating sanction levels will in particular be a consideration if an analysis of the current sanction legislation of administrative or criminal nature reveals significant differences amongst the Member States and if those differences lead to an inconsistent application of EU rules.

If $\mathrm{EU}$ action is required, the EU legislator needs to decide whether criminal sanctions are necessary or whether common administrative sanctions are sufficient. This will depend on a case-by-case assessment of the specific enforcement problems in a policy area along the guiding principles set out above.

There are a number of policy areas which have been harmonised and where it has been established that criminal law measures at EU level are required. This concerns notably measures to fight serious damaging practices and illegal profits in some economic sectors in order to protect activities of legitimate businesses and safeguard the interest of taxpayers: the financial sector, e. g. concerning market manipulation or insider trading; the fight against fraud affecting the financial interests of the 
European Union, ..., the protection of the euro against counterfeiting through criminal law ...

The Commission will further reflect on ways how criminal law could contribute to the economic recovery by helping tackle the illegal economy and financial criminality.

In other harmonised policy areas, the potential role of criminal law as a necessary tool to ensure effective enforcement could also be explored further. Indicative examples could be: road transport, ..., data protection, ..., customs rules ..., environmental protection, ... fisheries policy, ....internal market policies to fight serious illegal practices such as counterfeiting and corruption or undeclared conflict of interests in the context of public procurement.

These are areas which will require further assessment whether and in which areas minimum rules on the definition of criminal offences and sanctions may prove to be essential in order to ensure the effective implementation of EU legislation.

This analysis should take into account the following considerations:

The seriousness and character of the breach of law must be taken into account. For certain unlawful acts considered particularly grave, an administrative sanction may not be a sufficiently strong response. On the same line, criminal law sanctions may be chosen when it is considered important to stress strong disapproval in order to ensure deterrence. The entering of convictions in criminal records can have a particular deterrent character. At the same time, criminal proceedings provide often for stronger protection of the rights of the accused, reflecting the seriousness of the charge. The efficiency of the sanction system must be considered, as well as the extent to which and the reasons why existing sanctions do not achieve the desired enforcement level. The type of sanction that is considered to be the most appropriate to reach the global objective of being effective, proportionate and dissuasive should be chosen. An administrative sanction can often be decided and executed without delay, and lengthy and resource demanding procedures can thereby be avoided.

Administrative sanctions may for this reason be considered in areas where, for example the offence is not particularly severe or occurs in large numbers as well as in areas where administrative sanctions and procedures are suitable and effective for other reasons (e.g. complex economic assessments). In many cases, administrative law also provides for a broader range of possible sanctions, from fines and suspension of licenses to exclusion from entitlement to public benefits, which can be tailored to the specific situation. In many cases, administrative sanctions may therefore be sufficient or even more effective than criminal sanctions.

\section{CONCLUSION}

Even though the new legal framework introduced by the Lisbon Treaty does not fundamentally alter the possible scope of EU criminal law, it considerably enhances the possibility to progress with the development of a coherent EU Criminal Policy 
which is based on considerations both of effective enforcement and a solid protection of fundamental rights.

This communication represents a first step in the Commission's efforts to put in place a coherent and consistent EU Criminal Policy by setting out how the EU should use criminal law to ensure the effective implementation of EU policies. It needs to be designed focusing on the needs of EU citizens and the requirements of an EU area of freedom, security and justice, while fully respecting subsidiarity and the last-resort-character of criminal law.

For this purpose, the Commission will draft, ... sample language. This should guide the EU legislator whenever drafting criminal law provisions setting minimum rules on offences and sanctions. This would contribute to ensure consistency, increase legal certainty and facilitate implementation of EU law. The Commission will also set up an expert group to assist the Commission in gathering factual evidence and in launching further discussions about important legal issues with a view to ensuring an efficient implementation of EU legislation into the national criminal law systems of Member States. This includes for example:

- the relationship between criminal and non-criminal sanction systems; and

- the interpretation of criminal law notions regularly used in EU legislation, such as the notion of "effective, proportionate and dissuasive sanctions", "minor cases" or "aiding and abetting".

Based on a thorough evaluation of existing EU criminal law measures and continuous consultation of Member States and independent experts, the Commission will continue to develop the EU criminal policy over the coming years...." 